\title{
Struggle for the Right to Cover Up for Family Members: The Significance and Value of the Confucian Thought "Cover Up for Family Members" in Modern Society
}

\author{
TSENG Wei-Chieb*
}

\begin{abstract}
The argument for covering up for family members who had committed offenses was a core part of Confucian thinking, and a topic that has long been controversial. This idea tended to be deemed by traditional Legalist scholars and contemporary law-centered scholars as an outdated approach that compromised legal fairness, and thus should not be accepted by contemporary society. However, it is understood through Honneth's recognition theory that the "law" is in fact merely a principle of recognizing a person's identity as a member of civil society, and we cannot ignore that man also has an identity of the "family" relation that is connected to "love". The identity recognition based on the principle of "love" is an intrinsic need of humans, and also an essential link in the establishment of an integrated personality. The desire to cover up for a family member is nothing other than an attempt to rebuild an ethics-centered identity recognition, so as to avoid the materialization of humans by "laws".
\end{abstract}

Keywords: Confucianism, The Analects 論語, Mencius 孟子, cover up for the family members 親親相隱, Axel Honneth, theory of recognition, normative reconstruction

Prizadevanje za prikrivanje za družinske člane: pomen in vrednotenje konfucijske ideje o "prikrivanju za družinske člane« v moderni družbi

\section{Izvleček}

Razprava o prikrivanju za družinske člane, ki so storili kaznivo dejanje, je bila v samem jedru konfucijskega razmišljanja ter že dolgo predstavlja sporno temo. Tradicionalni legalistični učenjaki ter sodobni raziskovalci zakonov imajo to idejo pogosto za zastarelo ter menijo, da ogroža legalno pravičnost, zaradi česar je nesprejemljiva za sodobno družbo. Toda če sledimo Honnethovi teoriji prepoznavanja, ki pravi, da je »zakon« le princip prepoznavanja človekove identitete $\mathrm{v}$ okviru civilne družbe, potem ne moremo prezreti, da ima človek tudi identiteto v okviru družinskih odnosov, ki je povezana $z$ »ljubeznijo«.

TSENG Wei-Chieh, Adjunct Instructor, Department of Chinese

Literature, National Cheng-Chi University, Taiwan.

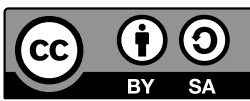

weichieh926[at]gmail.com 
Prepoznavanje identitete, utemeljene na principu »ljubezni«, je notranja človekova potreba in bistvena komponenta pri grajenju integrirane osebnosti. Želja po prikrivanju za družinskega člana ni tako nič drugega kot poskus, da se obnovi prepoznavanje identitete, ki izhaja iz etike, s čimer se izognemo »zakonsko« utemeljeni materializaciji človeka.

Ključne besede: konfucianizem, Analecte 論語, Mencius 孟子, prikrivanje za družinske člane 親親相隱, Axel Honneth, teorija prepoznavanja, normativna rekonstrukcija

\section{Introduction}

Confucianism is often criticized as incompatible with modern rule-by-law due to its support for “covering up for family members" ( qin yin 親隱), which is viewed as a righteous deed and a virtue in Confucian thought. ${ }^{1}$ The concept can be traced to “The Argument about Justice between the Governor of She 葉公 and Confucius 孔子” in The Analects of Confucius 論語. If the father steals a sheep, should the son report him or conceal his wrongdoing? From a ruler's standpoint, Governor of She considered it more valid to report, whereas Confucius, who took ethics' side, thought it more appropriate to conceal the father's crime (Lau 2010, 127).

There is another more extreme example in Mencius 孟子, “Emperor Shun 舜 in the Face of a Dilemma”. One of Mencius' disciples-Tao Ying 桃應—asked him “If Emperor Shun's father—the Blind Old Man (Gu Sou 䡰瞍)—murdered someone, what should Emperor Shun do?" Mencius answered, "He should not stop the executors from arresting the Blind Old Man."Tao Ying was confounded and went on inquiring, "As a son, shouldn't Shun do something to stop the arrest?" Mencius explained, "Executors have to prosecute their duties. How can they be interfered with? All that Shun could do was to leave behind the royal identity of Emperor and run away with his father to a lawless place and live happily ever after" (ibid. 2003, 303).

It is this cover-up-for-family-member idea in Confucius and Mencius'speeches that has often attracted criticism of Confucianism as a while, since it violates the idea of rule-by-law spirit, as Liu Qing-Ping notes:

1 Although the concept of "cover up for family members" is pervasive in contemporary law-it can even be traced back to Han dynasty in China-it is undeniable that it is still being measured by the standard of "justice" and Confucianism took the blame for spreading it. Accordingly, it has become an imperative to redefine the concept of "cover up for family members" and show that it is not only the result of civilized progression, but also a right gained through constant collision with the system. It is thus able to emphasize the "family" as the basis of interpersonal relationships and build up a humanized theory of justice based on the atomic-individual ethic of justice. As to the idea of "cover up for family members" in Chinese law, please refer to Fan Zhong-Xin (2004, 602-6). 
The main cause of people considering Confucian thought as a cradle that breeds corruption sits in the idea that blood relationship is prior to anything else. It positively approves of the deeds that are done to protect family members regardless of them violating the universal standards in social groups. (Liu 2004, 895)

Yet, as we can see, Mencius did not oppose the idea that murderers should be arrested and held responsible for what they did, nor did he deny of the primacy of law. However, in a sense, Mencius transcended the inflexible rule of law. What he proposed was a legal constitution that embraced humanity and, at the same time, political philosophy.

This can be supported by recognition theory, ${ }^{2}$ as raised by Axel Honneth-a member of Frankfurt School-to increase the value of the Confucian idea "cover up for family members" in modern society. ${ }^{3}$ Just as what Axel Honneth realized, modern society holds people in the captivity of the identity and human rights that the law is associated with. All human behaviors are seen through the eyes of the law. All we care about is "passive freedom"-what the law tells us to do and not to do, and we overlook the identity and relationships that we are born with, namely the ethical relations emphasized by Confucianism, such as the relationships between

2 Honneth's recognition theory is a statement or verification about the effectiveness and legitimacy between subjects, and is a theory with an attempt to sort out and reflect, systematically, the identity recognitions that people make of each other. By inheriting and criticizing the thoughts of Hegel and others, Honneth basically divided the interrelations of subjects into three levels: identity recognition of family relation, that of civil society and that of nation. (Hu 2015, 151-7)

3 The issue of "cover up for family members" has been widely discussed and debated by Chinese and Western scholars. In China, the book New Criticism of Confucian Ethics by Deng Xiao-Mang criticizes the idea. Criticism of the New Criticism of to Confucian Ethics and Collection of Debates on Confucian Ethic-Study of "Cover up for Family Members" by Kuo Qi-Yong, both respond to Deng's view and collect the debates by contemporary scholars on the issue. Lin Gui-Zhen also makes arguments on the issue in the book The Issue of "Cover up for Family Members" and Other Topics. In the Western world, Huang Yong discusses the issue in greater detail, and he focuses more on a son's remonstrations to his father and the buildup of moral character; and yet he overemphasizes the idea of a "moral agent" and overlooks the dilemma of multiplicity in a person in the concept of "cover up for family members". However, I am not going to delve into this debate in this study. Instead, I hope to raise a possible resolution to reduce the alienation caused by contemporary rule-by-law society and the law itself. Therefore, using Honneth's recognition theory to examine the past and scrutinize the present issue of "cover up for family members", and to understand contemporary thinking about "justice", this research aims to pave the way for an ethics of justice in the rule-bylaw society. Honneth's theory might not represent the universal opinion of contemporary society, but its basis on current introspection and criticism accords with the intention of this research. Although recognition theory might not be the only way to solve this problem, it is one of the best ways to explore the issue of "cover up for family members" in China and the western world. (Deng 2010; Kuo 2011; Lin 2013; Huang 2013, 139-50) 
father and son, brothers, husband and wife. Why do we throw over our ethical relations for what the law identifies us to be, and further throw away the right to protect such relations?

With cross-referencing, we can see that the Confucian idea of "cover up for family members" is quite similar to the criticism of the modern legal-based society presented by recognition theory. It also aims to present practical reasons and an ethics of responsibility in normative reconstruction.

\section{Necessity of Covering Up for Family Members: Reflection on Multiple Identities}

We can start by reflecting on the act of "covering up for family members", as set out in The Analects of Confucius and Mencius, and consider why the issue of sons reporting fathers' wrongdoing would trigger such a debate, and why idea of sons covering up for fathers would suffer such public censure in contemporary society. These questions must be probed from the perspectives of contemporary philosophical thought and the legal dimension that defines and clarifies the meaning of "human".

\section{Reflection: Deficiencies of Law-centered Scholars}

In his Analects, Confucius discussed the concept of "justice" ( $z h i$ 直 $)^{4}$ with Governor of She. Governor of She perceived the act of sons reporting fathers' theft as a just deed, whereas Confucius found justice, reversely, in the deed of "covering up", declaring that fathers or sons should be covering up for each other even when one of them had committed theft.

We can thus consider why the deed of "covering up for family members" would be appraised differently by Governor of She and Confucius, and also realize that the difference in their perspectives would further influence their recognitions of "justice". One of the key elements to why these differences exist is the two speakers' identities. The Governor of She spoke from the perspective of a law enforcement

4 D. C. Lau translated "zhi gong 直躬” in The Analects of Confucius as "straight", which means correct, upright, and candid. Similarly, James Legge translated it as "upright". These translations highlight the ancient language context, but if we read the term from the perspective of contemporary philosophy then we can comprehend it as "justice", which shows traditional Confucian universal values and breaks away from the limitations presented by the traditional context, which is to say, the feeling of being "straight" and "upright", from the social dimension and philosophical thought, is a deed of pursuing "justice". 
professional, whereas Confucius came from the angle of a philosopher, educator and sociologist (Quan 2000, 4-7), ${ }^{5}$ and thus defined "justice" at the philosophical level.

That is, as a law enforcement professional and administrator, the Governor of She assessed and judged a person's deeds and defined "justice" from the viewpoint of traditional law and punishment. As such, if anyone went counter to law, then he or she should be punished. The implementation of this punishment is then an act of justice, which indicates that the relationship between Governor of She and the people was based on law, which could be represented in the following order: "Governor of She-Law-the people". In his opinion, every person is an individual and every individual is a "legal person" before the law.

The term "legal person" is, however, equal to a term that we are familiar with, that of "human" in contemporary legal-based society. In this, every right and obligation is determined by law, with no exception. Judging from such an angle, the statement "Fathers cover up for their sons, and sons cover up for their fathers" (Lau 2010, 127) in Confucius is in defiance of the law, a form of injustice. It goes without saying that, in light of such an opinion, Mencius'statement with regard to Emperor Shun shielding his father, the Blind Old Man, who murdered someone, is beyond comprehension.

A Taiwanese legalist, Zhou Tian-Wei strongly condemned the son who "secretly carried the old man on his back and fled to the edge of the sea and lived there happily", and stated that even though it was a filial duty, it was a lawless deed (Zhou 1998, 49). He believed this caused immense harm to the fairness of law and was this no valid in contemporary society. A professor from the Department of Philosophy in Beijing Normal University, Liu Qing-Ping, also strongly criticized the idea of "covering up for family members" and thought it "a cradle that breeds corruption in Confucian thought". In short, "blood relationship before anything else" (Liu 2004, 895) is a concept that violates contemporary ethics.

\section{Criticism: Atomistically Isolated Individuals amid Modernism}

However, the legal focus that Zhou and Liu brought about is to be denounced. Neither is the view that Governor of She held, because, as Honneth stated, "in

5 We should not characterize the word "human" as defined by Confucius, but should ponder on what "human" is syntactically. How do we reach justice and stability in society through changing people's minds and deeds? Of course, Confucius, in some way, was a politician, but his thought was not confined to politics only. As Qian Mu said, he was a person who "mingled knowledge with emotions; mixed religion with wisdom; combined socialism with individualism". 
traditional law, everyone is a legal person" (Honneth 2005, 117-8), and we are deprived of our other identities and only live as "legal people", detached from the complex elements of a community.

The concept of the traditional "legal person" builds on the idea of "individuality", which is propped up by law, and each individual perceives the world from their own perception. They have to face happiness or sorrow, duty or right, on their own, because they are an individual and there are no connections among anyone. Such a concept entered the mainstream after Rene Descartes (1596-1650) and formed a dualism, as such, "based on epistemology and value theory, the basic unit in Western society is the individual" (Liu 2004, 736).

Honneth examined this phenomenon and indicated that people who adopt a strong sense of individuality basically succumb to the dangers of atomic theory. Each individual is alienated before the law, and is not seen as playing one of the many roles in an ethical community, and this hinders the sustainable growth of "ethical integration" (Honneth 2005, 17). This "ethical integration" values "intersubjectivity" over individuality, which is perceived as a detached being. It emphasizes the complexity and the multiplicity in a person, and integrates these in interpersonal relationships, aiming to understand the interactions between people to find the essence of the "complete person", instead of building up an independent "legal person" and then tacking on it the ethics and circumstances of exception and otherness (ibid.), kindling hostility and conflicts.

The concept of "covering up for family members", as presented in The Analects of Confucius and Mencius, was called in question by Tao Ying, the pupil of Governor of She and Mencius, and criticized by contemporary legal centralists. They perceived people as detached individuals, resorted only to the law for rationality, and left in oblivion the multiple identities and values of a being.

Here, multiple identities refers to a phenomenon in the interrelationships among people: everyone plays many different roles when in different situations. A woman can play the part of a mother, lover, wife, citizen, or professor. She, in her different roles, finds different obligations and shoulders various responsibilities (Liu 2004, 737). Yet the legal centralists and Governor of She thought it righteous for the son to report his father when the latter committed theft-a case recorded in The Analects of Confucius. They only saw the son as a citizen, and left out the fact that he is also a son.

From the idea of multiple identities, as in Honneth, we must recognize the multiple values endowed in a person, and see that there are three orientations to the interrelationships among people, which are emotional attachment, conferring of 
powers, and common value. These three orientations exist in beings with different modes of "recognition", and, accordingly, they lead to the development of distinctive potential moralities. "Emotional attachment" recognizes the righteousness of mutual existence by virtue of love; "conferring of powers" recognizes validity by virtue of law, and "common value" recognizes the social identity by virtue of unity (Honneth 2005, 102-3).

In other words, the Governor of She endowed a person with their rights by law, and it was by law that he assessed a person's responsibility. In the situation "When his father stole a sheep, he the son gave evidence against him” (Lau 2010, 127), we only see the identity of the son's citizenship and neglect his role in the family. The law only demands that a citizen act responsibly in terms of the law-there should thus be no concealing of lawless acts or people. Such a concept leaves out the compassion that a son should feel, and perhaps the above statement needs to be revised as follows to conform with the ideas awareness of the Governor of She and legal centralists: "When a citizen steals a sheep, the other citizens should give evidence against him."

\section{Development: An Integrated Personality with Multiple Identities in Confucian Ethics}

We could perhaps form the idea that the law sees a person as an independent and unattached individual, and each has their right and duty based on the ideas of atomism, and yet all the law actually does is emphasize a being's "legal person" identity, leaving out the multiple identities and values in a person. Such a problem emerges several times in the previous text-we judge a person solely by his identity as a "citizen" and demand that he does what should be done by a "citizen". We thus singularize and flatten a round character, and we neglect the fact that "citizen" does not stand for "human being".

We can consider it this way: aside from living in the same city, say, there is no connection between citizen A and citizen B. As such, perhaps it is reasonable to say that citizen $B$ is conforming to the principle of justice to report citizen $A$ after catching him stealing. However, if citizen $\mathrm{A}$ and citizen $\mathrm{C}$ are father and son, then we cannot expect citizen $\mathrm{C}$ to do the same thing as citizen $\mathrm{B}$ does, because, besides the identity of citizenship that the law has given, these two men are bound together by "love" and their blood relationship. The justice defined by law is not necessarily the justice defined by love. True justice is inclusive of a person's different orientations, and leaving out one of these means that it is not qualified to be called justice. 
Honneth realized that in a society where everyone is identified as a citizen, the relationship between individuals is based on the trading, while people's roles as family members start to wane, and thus alienation grows (Honneth 2000). The legal-centered "recognition of rights" prevails over the love-centered "recognition of emotion". An over-emphasized individuality leads to the end of certain dimensions in a person, and these dimensions are the most significant elements in Confusion thought-family ethics and family relationships, which refer to the relationship between fathers and sons in The Analects of Confucius. In professor Tu Wei-Ming's words, "families imbued with Confucian values are perhaps still the single most important social institution in imparting ways of learning to be human in East Asian societies" (Tu 1998, 135). Family relations are the core of Confucian thought, and are also the dimension Honneth took notice of.

Another question is why Confucius would say "Fathers cover up for their sons, and sons cover up for their fathers. In such behavior is straightness to be found as a matter of course" (Lau 2010,127). Why is covering up for family members an act of justice? It is because the intention of the act revolves around love, which binds people together emotionally. In such a situation, the identities of fathers and sons are valued, instead of identifying every father and son as a citizen, as the Governor of She and the legal centralists proposed.

Accordingly, and based on the theory proposed by Hegel (1770-1831), Honneth divided the standard of justice and the norm of freedom into "family", "civil society" and "country" (Honneth 2000), which are the important elements for people in a law-based society. They give meaning to family relationships before the law and highlight the significance of the "covering up for family members", showing that every individual is more than what the "law" defines them, and thus their duties and responsibilities are more diverse than what the "law" demands, because everyone is bound by relationships based on love. After seeing the importance of multiple values and identities, we will next take the discussion further into the rationality and necessity of "covering up for family members".

\section{Rationality of Covering Up for Family Members: Seeking Identity Recognition of "Family" Relations in the Suffering Due to Indeterminacy}

Since everyone possesses multiple identities, we start to see how love binds people together, and begin to value the identity a person bears in a family, rather than looking at people from a strictly "legal" angle and defining everyone as a "legal 
person". To get a clearer picture, we should ask why when there is a conflict between the role of a "family" member and "civil society" citizen, we should put our family-member role in priority and civil citizenship in the second place, with no exception? Why should we consider the possibility of covering up for family member when they commit a crime?

\section{An Irreplaceable Relation: "Family" Relation as the Identity Recognition of Essential Meaning}

First, we can consider this from the perspective of every individual's irreplaceability. As Honneth proposed, the dimensions of relationship between people are divided into "family", "civil society" and "country". If any one of these comes into conflict with the others, which should take precedence? This question is considered below.

The obstacles and possibilities of multiple identities are more easily comprehended if we take a look at the case of "Emperor Shun in the Face of a Dilemma" in Mencius: One of Mencius' disciples "Tao Yin asked, 'When Shun was Emperor and Kao Yao was the judge, if the Blind Old Man killed a man, what was to be done?"'(Lau 2003, 303). In this situation Shun has three identities: (1) To the Blind Old Man, he is a son, and thus a family member; (2) to judge Kao Yao, he is a supervisor, and thus part of civil society; (3) to the country, he is the emperor, and thus exists in relation to the country.

Most of the legal centralists would criticize Shun-the emperor-for sheltering his father and deem it as corruption and a disdain for law (Liu 2004, 894). And yet, such a condemnation is only seen from the angle of Shun as an emperor, and overlooks the fact that he is also a son. Mencius not only embraced Shun's identity as a son, but also put "family" before the law, and declared: "He (Shun) would have secretly carried the old man on his back and fled to the edge of the sea and lived there happily" (Lau 2003, 303).

Mencius placed "family" before "civil society" and even before "country", showing that the relationship between family members is irreplaceable. This corresponds to the observation made by Henry Rosemont Jr and Roger T. Ames: "family feeling (xiao 孝) is a prior and necessary condition for later extending and developing fellow feeling (ren 仁) for all others" (Rosemont and Ames 2008, 10-11)

That is to say, Shun possessed at least three identities, which are "son Shun", "superior Shun", and "Emperor Shun". However, the identity as a son is inborn, natural and destined, and the other two identities can be abandoned of one's free will 
(Liu 2004, 737); therefore, only the identity tied by love and family relationship is irreplaceable.

As such, why do people abandon their identities as family members, which they were born with, for the law that is not innate? Professor Chen Hong-Xue from Cheng-Kung University suggested that "We should not build up the civil society at the cost of ethical relations" (Chen 2012,14). This is also what Roger T. Ames pointed out, claiming that the family as an "in-group" ${ }^{6}$ possesses strong bonds, and through the "in-group" bond, every individual associates him- or herself with society, politics and the natural order; they are mutually beneficial to each other, and these roles are the keys to an individual's self-fulfillment (Ames 1995, 276, 278). This suggests that public order should be established based on the innate "in-group".

We definitely cannot abandon the inborn relationship between fathers and sons, which is supported by love. Neither should we define and assess a person in too rational a way, which is why the recognition theory proposed by Honneth inspires the current study: we do not have to abandon the relationship between parents and children, and we only have to see it as a limitation and balance it with law (Honneth 2013, 185). This concept goes hand in hand with the idea "cover up for a family member". Mencius said, "the only thing (that Kao Yao needed) to do was to apprehend him (the Blind Old Man)". He did not suggest that Shun prevent judge Kao Yao from enforcing the law, and neither did he think Shun could use his power to change the fact that his father-the Blind Old Man-had murdered someone. He should, however, have "looked upon casting aside the Empire as no more than discarding a worn shoe" (Lau 2003, 303). This is a decision made after considering the limitation of a family relationship.

By the principle of multiple identities, "father-love-son" should be placed before "citizen-law-citizen".

\section{An Inseparable Relation: "Love" as the Key to Forming Normal Personal Traits}

We then need to realize that Confucius thought it righteous for the man whose father stole a sheep in The Analects of Confucius and Shun, whose father murdered people, in Mencius, to cover up for a family member because of the irreplaceability and indivisibility of the bond between fathers and sons. Yet, if we think about it

6 This refers to a group of people that consciously care for one another, collaborate, unite and are intimate with each other. The opposite of "in-group" is "out-group". 
from the perspective of dualism and see everyone as an atomized individual, we naturally cannot see the connection between them and thus come to judge things like the legal centralists.

However, an unattached individual earns their recognition in the society only through law-we recognize the legality of people living in society by virtue the of law, but this does not make a person complete. The completeness of a person stands on their own distinctiveness, which refers to the recognition and self-gratification that one feels in the role as a family member, as achieved by love (Honneth 2005, 28). That is, if we only see a person as a "legal man" and overlook the importance that emotion plays in society, we will be materialized and that leads to alienation. From the perspective of psychoanalysis, this alienation triggers psychological disorders and results in morbidity (ibid., 103-4).

It is thus not hard to grasp that losing the recognition between family ties, which grow based on love, leads to a morbid personality. During the Cultural Revolution (1966-1976) in China, there were many denouncements and accusations between fathers and sons, teachers and students. In East Germany (1945-1990), secret policemen caused many couples and friends to report on each other, have negative effect on character building. Confucius and Mencius shared the same idea, because the core of their theories was the "family", which is a very significant characteristic in Confusion thought. One of the Confucian classics, Liji (Book of Rites), states that "who wanted their pure and excellent character to shine in the world would first bring proper government to the empire; desiring to bring proper government to the empire, they would first bring proper order to their families." (Hall and Ames 1992,164)

In the context of "the argument about justice between the Governor of She and Confucius", Confucius deemed it righteous to give priority to the father, so he suggested that the con should cover up for his father; in the context of "Emperor Shun in the Face of a Dilemma", Mencius advised Shun to escape with his father to the edge of the sea and live there happily with him (Lau 2003,303). This is the serenity and bliss brought about by the relationship between parents and children.

As Honneth suggests, in the father-son relationship tied by love, the one that loves and the one that is loved can open their hearts and recognize each other due to this love. The two are thus no longer two individuals. There no longer exists a boundary between them, and they are in a state of mutualism (Honneth 2005, 112). That is, in the situation where the father stole a sheep, the son and father were no longer two individuals but they were mingled as one "father-son". In the situation where the Blind Old Man murdered people, there is no boundary between Shun and his father, they are "Blind Old Man-Shun". They mingled as 
one because of "love". We keep emphasizing that we should abide by law, but in this case, if Shun chose to comply with the law he would be pushed away from his state of oneness- "Blind Old Man-Shun". The meaning of family love would be lost, rendering him lonely, empty, and confused, which means, in Honneth words, he would be "suffering from indeterminacy" (Honneth 2000).

That is, the relationship between individuals should be built on "affection"-every norm and logic rests on "feeling", or else it loses any rationality for being human beings. Just as $\mathrm{Li} \mathrm{Ze-Hou} \mathrm{indicated,} \mathrm{people} \mathrm{are} \mathrm{beings} \mathrm{with} \mathrm{emotions,} \mathrm{and} \mathrm{this} \mathrm{is}$ why it is necessary to build everything upon "affection"-otherwise, people will get lost in a ruthless absolute rationalism and order, which is why $\mathrm{Li} \mathrm{Ze-Hou} \mathrm{em-}$ phasized the value of emotion-based substance" (qing benti 情本體) that evades the predicament of "killing in the name of justice" (Li 2008, 54-71); why Confucians proposed "the right of covering up for family members", and why Honneth presented recognition theory.

The concept "covering up for family members" is different from what Liu ChingPing said, "put blood relationship before anything else" (Liu 2004, 895), but it comes from deep inside everyone, the intuition that we are endowed with-to protect our family members-and once the connection of love is cut off, we are no longer "complete".

\section{Quest to Cover Up for Family Members: Struggle for the Right to Cover Up for Family Members}

It is acknowledged, based on the idea that covering up for family members is rooted in the family affection, that it is possible to establish the "family"-level relationship as the foundation of all people, such that integrity and normality can be assured. That is, covering up for family members is reasonable and necessary. From exploring its past, present and future, we can further understand how this idea can more closely conform to the principle of justice.

\section{Awakening: Challenge against Law-centered Philosophy}

Those against the idea of covering up for family members criticize Mencius' argument that Shun should have abdicated and run away along with the Blind Old Man. Chou Tian-Wei, for example, argued that would be in contempt of justice (Chou 1998, 55). Qian Mu also stated that "covering up for the father's act of stealing sheep is a minor crime; running away with the father who had committed 
murder is a felony; as an Emperor, Shun's act of abandoning the duty of running a nation is beyond felony" (Qian 1981, 118-9). We now can ask the following: If covering up for family member is right and due, why did Mencius insist that Shun run away with his father?

In fact, Shun's running away with the Blind Old Man did not violate the concept of covering up for family members, but instead had the full reasonableness and rightfulness of doing so. We can see from the Governor of She's idea on the case "when his father stole a sheep, the son gave evidence against him", and in its presentation as a just action in The Analects of Confucius (Lau 2010,127), that "covering up for family members" was not universally accepted, and even seen as incorrect in the eyes of the ancient rulers.

In other words, if we apply Honneth's concept of three divisions, which are "family", "civil society" and "nation", to ancient society, the level of "family" is then tied by "love" to the ruler. Therefore, besides justice, Confucius and Mencius attempted to take ethics into their consideration of justice and tried to promote the idea of covering up for family members, which is also what Honneth advocated. He suggested that we should be able to ascertain who is being suppressed and fight for their rights, based on the sensitivity of our morality ( $\mathrm{Hu} 2015,195)$. In this, the Confucians and Honneth are consistent.

As to why Shun had to abandon his throne and flee to the edge of the sea with his father, it is because he was covering up for family members. Because the concept of this action had no yet come into shape, nor did such a right exist, Shun had to break the system to manifest his own ideal. Just as Honneth notes, this was a "struggle for recognition" (Honneth 2005, 50). That is, the system at that time focused on justice and left few footholds for parent-son relationships to stand on. The law required people to report the criminal acts of their relatives, in conflict with the recognition of relationships tied by "affection" and by "justice", in which the subjects are forced to recognize each other in the "citizen-law-citizen" manner, while that in the "father-love-son" manner is not allowed. It is thus necessary to "embody the conflict between subjects" (Hu 2015,180) to struggle for the right of covering up for family members.

For Confucius and Mencius, emphasizing the importance of "legal" relationships and forcibly waiving the relationship of "love" was an injustice, and thus it was necessary to struggle so that more "affectionate" relationships be realized, just as Shun did. Shun, as Honneth states, took an action "against the mainstream culture in order to be respected" when a certain value was not recognized (Honneth $2005,129)$. 


\section{Conflict: Seeking the Right to Cover Up for Family Members through Struggles}

Confucius' and Mencius' building of the primitive attachment in ethical relationships and, in the context of Confucian classics, Shun's struggle for the right of covering up for family member, did succeed in Chinese history, and the idea became a mainstream one. ${ }^{7}$ On the whole, in post-Han Dynasty China the law was inclined toward accepting the right to cover up for family members (Fan 2004, 602-6). Taiwan and China both preserve this tradition in the present day (Chen 2012,14). ${ }^{8}$

Now, how did the idea of covering up for family members become the mainstream in China? Why did it succeed in being accepted after all the struggles it had faced? The fact that the concept is now widely accepted proves people's need for primitive attachment; it also embodies the Confucian value of ethical thinking. Chou Tian-Wei criticized Mencius for his belief that "ethics itself is the source of order", because it led to the corruption of the legal order. (Chou 1998, 58). However, when judging from Honneth's theory of three divisions, which are "family", "civil society" and "nation", Mencius belief is tenable. As stated above, when losing the recognition that comes from family ties, which grow on love, then this leads to a morbid personality and may even cause a sociopathic one.

That is to say, the identification recognition in a "love"-connected "family" relationship, as argued by Honneth, is a relationship in men's most primitive experience, also referred to by Hegel as the intrinsic need for "ethic anticipation" (Honneth 2005, 45). Only when this essential need is satisfied can the meaning of "love" for individual development be integrated into social ethics, i.e., the recognition of an identity relationship at the "civil society" and "nation" levels (ibid., 44). This is exactly what Confucian thinking means by an "arithmetic of love"-a man's "network of relations is like a ripple; no matter how far it reaches, the energy is always the greatest at the center" (Tan 2002,173). It may not be appropriate to say that ethics itself is order, but ethics absolutely is the source of order.

In this regard, Guan Zhong - the prime minister of Qi-who Confucius highly praised, once advised Duke Huan of Qi 齊桓公 by saying that Yi Ya 易牙 “should

7 The scenario of Shun "secretly carrying the old man on his back and fleeing to the edge of the sea" was a philosophical hypothesis. However, the existence of such scenarios in Confucian classics really epitomizes early Confucians' struggles for the right to cover up for family members, and is also a reflection of the reality in ancient Chinese society.

8 Apart from the founding of the People's Republic of China in 1949, the then Communist Party of China adopted a comprehensive strategy of criticizing Confucianism, where they revoked the right of covering up for family member sin the law. But the ethical tragedies that resulted conflicts between parents and children during the 1966-1976 Cultural Revolution caused serious reflections. In 2012, China reinstated the provision of covering up for family members in its criminal law. 
not be appointed to assist the lord as he killed his own child to ingratiate himself with the lord, which is inhumane” (殺子以適君, 非人情, 不可), and Kai Fang 開方 "should not be appointed to assist the lord as he betrays his own parents to ingratiate himself with the lord, which is inhumane” (倍親以適君, 非人情, 不 可) (Takigawa 2007, 542). It is thus clear that regarding the "family" relationship, which is tied by love, as one of the basic elements to achieving justice and order is one of the common Confucian characteristics, and the profound exhibition of such an ideal in the assertion of covering up for family members is not only logically reasonable, but necessary.

\section{Reconstruction: To Incorporate the Right of Covering Up for Family Members in the Law}

Certainly, in emphasizing the right of covering up for family members the Confucians focused on ethics as the core of the situation; that is, perfecting people's identity recognition of the "family" relation by establishing the inter-subject networks that are "love" connected. That, however, is not as what Chou Tian-Wei stated, claiming instead that "ethics was considered by him (Mencius) to have a status above justice" (Chou 1998, 50). Rather, it is perhaps better to say that the Confucians believed that the recognition of the identity relation of the "family" was (and is) the foundation of a "civil society" and "nation", and that without the identity recognition of "family" people will have personality problems and it will be difficult for real justice to be served.

In the networks of relations, just as Honneth stated, the forms of recognition of "love" and "law" are equally important, or we should say that "love" and "law" should coexist in society (Honneth 2005, 184-5). According to Mencius' argument, if Shun had carried his murderous father and fled to the edge of the sea, this this would mean that he denied the importance of the law, because if so Mencius would not have said "the only thing (that Kao Yao needed) to do was to apprehend him", and further "how could Shun stop it (the apprehension of Blind Old Man)? Kao Yao had the authority for what he did" (Lau 2003, 303). According to Chen Hong-Xue, were it not for Shun's high affirmation of the law, why should he flee with his father, as he could have freely prevented, with his authority as the Emperor, Judge Kao Yao from enforcing the law (Chen 2012, 14-15).

Hence it is appropriate to say that Shun's escape is a decision made in honor of the law. Only through strategic conflict to highlight the confrontations between the relationship recognitions of "family", "civil society" and "nation" can the differences be made in universal value (Honneth 2012, 150), and this further prompts 
the unison of "love" and "law". When every kind of relationship recognition is tied to the other, the contradiction between them will ebb away (Foucault 1977,113).

The purpose of the quest to cover up for family members is not to justify the actions of the relatives of the criminals, but to strike a balance between "love" and "law". How to allow every subject in the system of multiple identities and diverse values to have a place of balance amid conflict is exactly what the Confucians meant by the quest for covering up for family members.

As such, what the Confucians tried to seek in the scenario of the "dilemma facing Emperor Shun" was that each of the subjects, namely Shun as the Emperor, Shun as a son, Kao Yao as a law enforcer, Blind Old Man as the criminal, Blind Old Man as a father, a victim, and the family of the victim, would be able to have a balance within the relations of conflict. And yet society only judges Shun-the Emperor, Kao Yao — the law enforcer, and Blind Old Man — the criminal-based on "law", identifying them as a "criminal" and "the family member of the criminal", and neglecting their identities as "father" and "son" that originate from love. Therefore, this scenario highlights the need for covering up for family members, although it does not deny the Blind Old Man's guilt, nor the victim's right for justice, and the victim's families appeal to the law. Instead, it hopes to achieve an ideal justice that is more easily accepted by everyone through the continued and constant fights between each subject.

\section{Conclusion}

It is clear from the discussions presented in this study that the idea of covering up for family member is a quest for the identity recognition of the "family" relation that is based on "love". Such a quest was also a contradiction to the Chinese Legalists' attempts to dominate people by the absolute power of the "law". Chinese history has proved that the Legalists' original thinking about cases like "when a father stole a sheep, the son gave evidence against him" led to a time of accepting the concept of covering up for family members after Confucius, Mencius and others had fought for its validity. Moreover, this right was then internalized, through the process of debate, into the "law" of later ages-from Han dynasty to today's China. This corresponds with Honneth's idea, which suggests that the values of ethics and moralities have to constantly collide with social and legal norms. What we obtain out of the collision and negotiation is the unison of "love" and "law". Therefore, ethics and moralities should be a part of the law, and we should not separate them. 
Legal centralists tend to define and evaluate every person and deed solely in relation to the law, which possesses absolute universality, and thus they exclude the existence of a morality which is supported by love. Instead of the model of the Kantian theory of justice, we should seek an absolutely universal truth and equality (Hu 2015, 195), and should, as Honneth argued, seek the integration of the recognitions of each other's identities during constant struggle. At first, Confucian scholars in China struggled for the right of covering up for family members, and then successfully created, by integration, new definitions of justice, making covering up for family members part of the new "legal" norms. Thanks to this, the profound and humane idea of covering up for family members became widely accepted, and this has helped in integrating ethics and legal norms.

\section{References}

Chen, Hong-Xue 陳弘學. 2012. “Cong xiandaifa guandian lun rujia 'gui fan youwei' siwei一yi kong, meng, xun sanzi wei zhuyao kaocha duixiang 從現代 法觀點論儒家 ‘規範優位’ 思維一以孔、孟、荀三子為主要考察對象 (Analyzing the Confucian Way of 'Normative Priority Thinking' from the Modern Law Point of View-Based on Confucius, Mencius, Xun Sanzi-As the Main Study Objective)." Gaoying keda renwen shehui kexue xuebao 高應科 大人文社會科學學報 (K.U.A.S. Journal of Humanities and Social Sciences) 9 (2) (12): 1-22.

Chou, Tian-Wei 周天瑋. 1998. Sugeladi yu Mengzi de xuni duibua一jiangou fazbi lixiangguo 蘇格拉底與孟子的虛擬對話一建構法治理想國 ( $A$ Virtual D $i-$ alogue Between Socrates and Mencius: The Variations of Chinese and Western Jurisprudence in Pursuit of an Ideal State of Law). Taipei: Tianxia Yuanjian Press.

Deng, Xiao-Mang 鄧曉芒. 2010. Rujia lunli ximpipan 儒家倫理新批判 (New Criticize to Confucian Ethics). Chongqing: Chongqing University Press.

Fan, Zhong-Xin 范忠信. 2004. “Zhongxi falu chuantongzhong de 'qinqin xiangweiyin’ 中西法律傳統中的“親親相為隱” (The Idea ‘Cover up for Family Members' in Chinese and Western Legal Tradition).” In Rujia lunli zhengmingji-yi “qinqin xiangyin” wei hexin 儒家倫理爭鳴集一以 “親親相隱” 為核心 (Collection of Debates on Confucian Etbics-Study on "Cover up for Family Members"), edited by Kuo Qi-Yong 郭齊勇, 601-5. Wu Han: Hubei Educational Press.

Guo, Qi-Yong 郭齊勇. 2011. Rujia lunli zhengmingji-yi "qinqin xiangyin" wei bexin 儒家倫理爭鳴集—以 “親親相隱” 為核心 (Criticism of “Nerw Criticism of Confucian Ethics”). Wuhan: Wuhan University Press. 
Hall, L. David, and Roger T. Ames. 1995. Anticipating China: Thinking through the Narratives of Chinese and Western Culture. New York: State University of New York Press.

—, trans. 1992. Liji (Book of Rites). ICS Ancient Chinese Text Concordance Series. Hong Kong: Commercial Press.

Honneth, Axel. 2000. Suffering from Indeterminacy: An Attempt at a Reactualization of Hegel's Philosophy of Right: Two Lectures. Amsterdam: Uitgeverij Van Gorcum.

—. 2005. Wei chengren er douzheng 為承認而鬥爭 (The Struggle for Recognition: The Moral Grammar of Social Conflicts). Translated by Hu Ji-Hua 胡繼華. Shanghai: Shanghai Renmin Press.

- 2012. Quanli de pipan: pipan shehui lilun fansi de jige jieduan 權力的批判: 批判理論反思的幾個階段 (The Critique of Power: Reflective Stages in a Critical Social Theory). Translated by Tong Jian-Ting 童建挺. Shanghai: Shanghai Renmin Press.

—. 2013. Ziyou de quanli 自由的權利 (Freedom's Right: The Social Foundations of Democratic Life). Translated by Wang Xu 王旭. Beijing: Social Sciences Documents Press.

Hu, Yun-Feng 胡雲峰. 2015. Guifan de zhongjian: guanyu buonaite de chengrenlun 規範的重建: 關於霍耐特的承認論 (Reconstruction of Norm: About the Recognition Theory of Honneth). Shanghai: Shanghai Renmin Press.

Huang, Youg. 2013. Confucius: A Guide for the Perplexed. London: Bloomsbury.

Lau, Din-Cheuk, trans. 1992. The Analects: Confucius. Hong Kong: The Chinese University Press.

—, trans. 2003. Mencius. Hong Kong: The Chinese University Press.

Li, Ze-Hou 李澤厚. 2008. Shiyong lixing yu legan wenhua 實用理性與樂感文化 (Pragmatic Reason and A Culture of Optimism). Beijing: SDX Joint Publishing Company.

Lin, Gui-Zhen 林桂榛. 2013. “Qinqin xiangyin” wenti yanjiu ji qita “親親相隱” 問題研究及其他 (The Issue of “Cover up for Family Members” and Other Topic). Beijing: China University of Political Science and Law Press.

Liu, Jun-Ping 劉軍平. 2004. “Rujia ‘qinqin xiangyin' de lunli yiju he falu yaoqiu 儒家 ‘親親相隱” 的倫理依據和法律要求 (The Ethical Basis and Legal Appeal of Confucian the Thought 'Cover up for Family Members')." In Rujia lunli zhengmingji一yi “qinqin xiangyin” wei hexin 儒家倫理爭鳴集一以“親 親相隱” 為核心 (Collection of Debates on Confucian Ethics-Study on "Cover up for Family Members”), edited by Kuo Qi-Yong郭齊勇, 735-50. Wu Han: Hubei Educational Press.

Liu, Qing-Ping 劉清平. 2004. "Meide haishi fubai?—xi Mengzi zhong youguan shun de liangge anli 美德還是腐敗? 析《孟子》中有關舜的兩個 
案例 (Virtue or Corrupt? -Discussing Two Cases About Shun in Mencius)." In Rujia lunli zhengmingji-yi "qinqin xiangyin" wei hexin 儒家倫理 爭鳴集—以 “親親相隱” 為核心 (Collection of Debates on Confucian Ethics—Study on "Cover up for Family Member"), edited by Kuo Qi-Yong 郭齊勇, 888-95. Wu Han: Hubei Educational Press.

Quan, Mu 錢穆. 1981. Shuangxi duyu 雙溪獨語 (Monologue in Shuangxi). Taipei: Student Publishing House.

—. 2000. Lunyu yu kongzi 論語與孔子 (Confucius and The Analects). Taipei: Sushulou Culture and Education Foundation.

Rosemont, Henry Jr., and Roger T. Ames: "Family Reverence (xiao 孝) as the Source of Consummatory Conduct (ren 仁).” Dao: a Journal of Comparative Philosophy 7 (1), 5: 9-19.

Takigawa, Kametarō 瀧川龜太郎. 2007. Shiji huizhu kaozheng 史記會注考證 (Collection of Note and Research for Record of the Grand Historian). Taipei: Tangshan Press.

Tu, Wei-Ming. 1998. "Probing the 'Three Bonds' and the 'Five Relationships' in Confucian Humanism." In Confucianism and the Family, edited by Walter H. Slote and George A. De Vos, 121-36. Albany: State University of New York Press. 